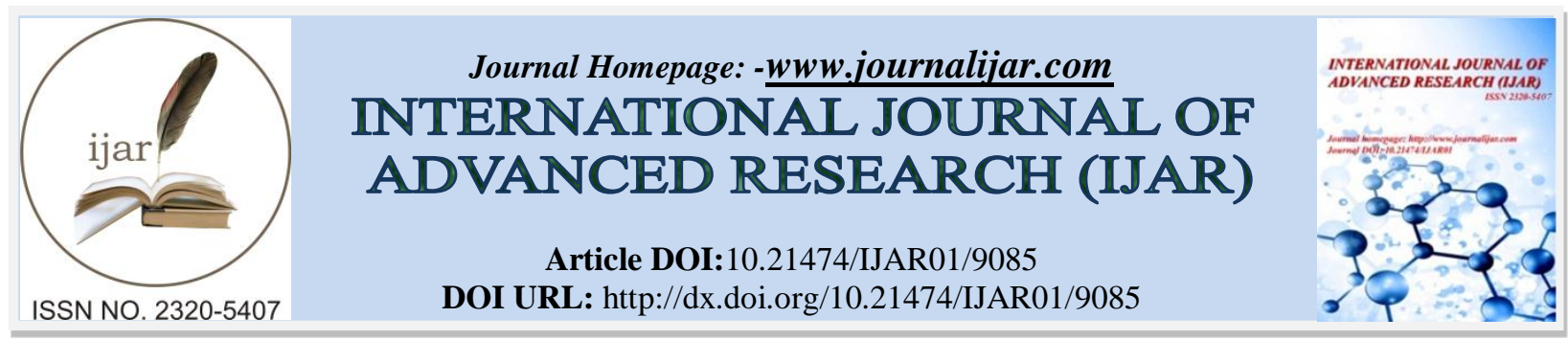

RESEARCH ARTICLE

\title{
THE EFFECT OF EMOTIONAL INTELLIGENCE, DISCIPLINE AND WORK MOTIVATION ON THE SESKOAL PRESCRIPTION DECISION MAKING.
}

Firdaus, Sylviana Murni and Matin.

Department of EducationalManagement, Graduate School, Universitas Negeri Jakarta, Pulogadung East Jakarta, 13220, Indonesia.

\section{Manuscript Info}

Manuscript History

Received: 16 March 2019

Final Accepted: 18 April 2019

Published: May 2019

Key words:-

emotional intelligence, discipline, work motivation and decision making.

\section{Abstract}

The purpose of this study was to study the effect of emotional intelligence, discipline and work motivation on decision making of Seskoal soldiers. This study uses a quantitative approach with survey methods. The sample from this study was 120 Seskoal soldiers in Jakarta. The results of this study indicate that; 1) positive direct influence of emotional intelligence on decision making of 0.380 with a tcount of $6.057,2)$ positive direct influence of discipline on decision making amounting to 0.368 with a tcount of $5.880,3$ ) positive direct effect of work motivation on decision making at 0.351 with a tcount amounting to $5,271,4)$ positive direct effect of emotional intelligence on work motivation of 0,345 with a tcount of $3,712,5$ ) positive direct influence of discipline on work motivation of 0,339 with a tcount of $3,646,6)$ positive direct influence of emotional intelligence on discipline of 0,317 with $t$ count is 3.174 . Thus improving the decision making of Seskoal soldiers can be achieved well if there is a strong influence of emotional intelligence, discipline and well-motivated work motivation.

Copy Right, IJAR, 2019,. All rights reserved.

\section{Introduction:-}

Introduction, Humans in everyday life are always involved in an action where the action is a reflection of the results of the decision making process, so that humans are very ordinary in making a decision, and even that decision has often been done repeatedly. Starting from the problems that are very simple to the problems that are quite complex and complex so that demands for a lot of consideration and depth in determining a decision making and decisionmaking is done in a conscious or unconscious manner. The purpose of decision making is to get an optimum result from various alternative choices. In real life there is no problem that only has a criterion, in each problem has more than one criterion (multi-criteria) and the problem is the actual decision making process (Milan, 2011). And Hillson also emphasized that if there were more than one choice or the results were uncertain, then a decision was needed (David, 2014). Decision making is taken intentionally, not by accident, and may not be arbitrary. First the problem must be known and clearly formulated, while the solution must be based on the selection of the best alternative. The Indonesian National Army Navy is part of the Indonesian National Army (TNI) which is responsible for the defense operations of the Republic of Indonesia in the Sea. The readiness of the Indonesian Navy in carrying out the task of defending the sea is determined by various components of power which include personnel, the main tools of the weapons system, and the system of methods. In the Navy the people are not armed but weapons are manned. 
Managing this weaponry is of course with certain qualifications and responsibilities. The burden of responsibility carried out by the Indonesian Navy requires a good and professional human resources education system. This decision was taken at the Naval Command and Staff School (SESKOAL). Seskoal is the highest general development education in the Navy, and has a main task in the deepening of material on the field of war and the study of defense issues at the strategic level and operations within the Navy. In Seskoal this is where the Student Officers are forged to become strategic level maritime state defense scholars, where learning activities include lessons in class, discussion and practice concerning the fields of study in Structures, Strategy, Management, Logistics, Operations, Social Communication and Science and Technology concerning the latest important issues, individual paper work (Taskap) and analysis. Then there are several top activities such as Planning and Strategy System Exercises, Marine Security Decision Making Exercises, Strategy Forums, Strategy Seminars, Lagistic Seminars, Taskap Presentations, Joint Operations Joint Program Programs and Joint Structural Activities Programs. Learning facilities in Seskoal include classrooms and discussion rooms, judicial facilities and libraries, in addition there are other facilities such as messing for lodging for Student Officers, hospitals, sports facilities, such as fitness rooms, tennis courts, table tennis, basketball, volleyball, golf and others including facilities for worship according to their respective religions. All of these facilities are directed to support the smoothness and needs of Student Officers who are studying in Seskoal (wikipedia : 2018). With the current condition of Seskoal, it is expected that it will be able to help smooth the tasks in Seskoal and the objectives of the educational institution will be achieved. This success also does not escape the ability of the personnel inside it, the Seskoal soldiers. The soldier referred to here is "all members of the TNI, both the army, navy and air force, ranging from the lowest to the highest rank are called Soldiers or Soldiers." (Cipir : 2018). So Seskoal soldiers are all military personnel serving in Seskoal starting from the lowest rank to the highest rank with activities carrying out Seskoal main tasks and other tasks according to the planned activity that has been set. Every Seskoal soldier should be consistent with his decision taken. The decision of no one was hesitant in the hope that all Seskoal soldiers could carry it out. Humans as a resource that cannot be controlled, human resources are the most important capital and wealth of every activity, humans as the absolute most important element are analyzed and developed. Time, energy, and ability can really be used optimally for the interests of the organization and individual interests, because human beings have reason, thoughts, passions, desires, and others. Human resources are different from other resources, where there must be an encouragement in humans themselves to create a productivity, the motivation is called motivation. Wibowo (2005) motivation is the reason, the impulse that is in human beings which causes people to do something or do something. Increase staff motivation by giving them feelings of belonging, loyalty, trust and values that encourage them to think positively about themselves and the organization. Motivation raises a passion for work, develops professionalism in realizing organizational goals, ultimately will lead to job satisfaction and reluctance to leave the organization and right in making a decision. From the description above it is assumed that the problems that occur are caused by the weak decision making on human resources in this case the soldiers. Weak decision making can be influenced by various factors including: emotional intelligence, discipline, and work motivation

\section{Literature Review}

The main distinguishing character in the context of management strategy is ability in decision-making strategies, amid the uncertainty of the environment at the same time the company organization is getting bigger and more complex. The decision making process becomes a complicated and increasingly difficult process, where decision making is the accuracy of achieving goals and reducing the level of uncertainty or lost. Wheelen and David (2012) assert that decision-making strategies fulfill at least three characters in the decision-making process namely, "Unlike many others decisions, strategic decisions and entire organizations and have three characteristics can be interpreted that in decision making strategies in connection unlike many other decisions, strategic decisions deal with the longterm future of the entire organization and have three main characteristics:

1. Rare, strategic decisions are usually unusual and usually have no precedent to follow.

2. Consequences, strategic decisions substantially because of background and demands (demand), forcing commitments from individual people, functions and structures at all levels.

3. Guidelines, strategic decisions that are set as precedents for the long-term future actions and overall existence of the company's organization.

The five steps of the Decision Making Process include (1) Identifying and defining the problem, is to find and define the problem. Information gathering and deliberation are very important at this stage. The way problems are defined can have a big impact on how the problem is resolved, and what important decisions need to be explained. (2) produce and evaluate alternative solutions. After a problem is defined, it is time to gather facts and information to be resolved. This is where we explain what is known and what needs to be known. (3) choosing the preferred action 
program, this is the point where the actual decision is made to choose the program of action taken. (4) implementing the decision, After the decision is made, action must be taken to be fully implemented and (5) evaluating the results. The decision making process is not complete before the results are evaluated. If the desired result is not achieved or if unwanted side effects occur, corrective action must be taken. Decision Making is a problem-finding process, starting from the background of the problem, Identifying the problem, to forming conclusions or recommendations .

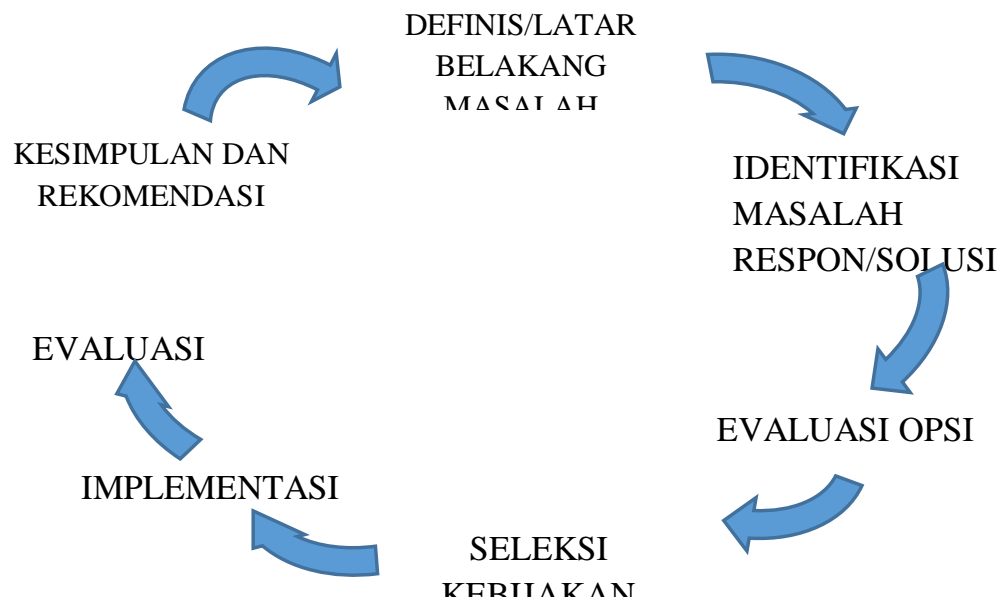

Every human has several unique potentials including Intellgeince Quantient (IQ) Spiritual Quotient (SQ), Adverse Quotient (AQ), Cretivity Quotient (CQ) and Emotional Quotient (EQ) which can be explained as follows: Intellgeince Quantient (IQ) is a measure of someone's intelligence / intelligence level or it can also be interpreted as a person's ability to capture information and learn new things. IQ is the general capacity of a person to do or do something and therefore relate to reasoning / thinking. Intelligence is the overall ability of individuals to think and act logically, directed and cultivate and master the environment effectively (Marten Pall, 1993). Robin and Timothy (2007) provide a limit that motivation is a process that explains an individual about the intensity, direction and persistence of trying to achieve a goal. Intensity is concerned with how one tries hard. Directions or directions pertain to business quality and consistency while persistence is concerned with a measure of how long a person can maintain his business. Thus it can also be said that motivation is a psychological process, where interactions occur between attitudes, needs, perceptions, learning processes and problem solving. According to Pamela \& Oloko Motivation (2015) in her research the key of successful organizations is to maintain the continuity of work within the organization by means and strong assistance to survive. Motivation is to provide the right guidance or direction, resources and rewards so that they are inspired and interested in working the way you want. Chukwuma \& Obiefuna Motivation (2014) in his research the process of generating behavior, maintaining behavior progress, and channeling specific behavioral actions. Thus, motives (needs, desires) encourage employees to act. Motivation is a process that starts with a need in human beings that creates a vacuum in a person. Motivation is a process where needs encourage a person to carry out a series of activities that lead to achieving certain goals. Goals that if successful are achieved will satisfy or fulfill those needs. Steers \& Porter (in Miftahun \& Sugiyanto 2010) states that work motivation is an effort that can cause a behavior, direct behavior, and maintain or maintain behavior that is in accordance with the work environment in the organization. Work motivation is a basic human need and as an incentive that is expected to meet the desired basic needs, so that if these needs exist will result in success in an activity. Employees who have high work motivation will try to get the job done in the best possible way. Work motivation according to Baron \& Greenberg (1990) in his theory "Expectancy Theory" is the result of three beliefs that each person has including: (a) expectancy, believing that every effort will produce results, (b) instrumentally, believing that every achievements will be rewarded or rewarded, and (c) valence, rewards or valuable rewards for recipients According to Donovan (2016) states, "motivation is a set of energetic forces than originates, both within as well as beyond individuals, to initiate work-related behavior and to deteminate the form, direction, intensity and duration". Motivation is a set of energy power from originating both inside and outside the individual, to initiate work-related behavior and determination of form, direction, intention, and duration. Meanwhile Ivancevich (2016) defines that: "Motivation" is the attitude that predisposes a person to act in an objective goal-oriented way. It is an internal state that directs a person 's behavior. This means that motivation is an attitude that influences a person to act with a specific purpose 
and a directed way. And this is an internal condition that guides someone to behave or do something. According to George and Jones (2009) explained, "Work motivation can be defined as the psychological forcer within a person that determines the direction of a person's behavior in an organization, a person 's level of effort, and a person' s level of percistence". This means that work motivation is a psychological impulse in a person that determines the direction of organizational behavior, level of effort and level of perseverance. Direction of behavior is a person's behavior in working in accordance with the mechanisms and rules set by the organization. While the levels in an effort to show how someone works in accordance with behavioral choices in carrying out their main tasks. In terms of the level of perseverance shows the level of someone in facing various obstacles, obstacles and how to overcome them. In line with the research conducted by Amir Sohail (2014) in his research stated that "Work motivation is a process that directs and sustains the performance. Motivation encourages employees internally towards actions which help them to achieve goals or specific tasks that are assigned to him. Based on some of the definitions and discussion above, it can be synthesized that the work motivation of soldiers is conditions inside and outside individual soldiers that cause diversity in the intensity, quality, direction and duration of work behavior in the organization, with indicators (1) assessment of work, (2) initiate in carrying out work, (3) be responsible for tasks assigned.

\section{Research methods:-}

the research method that will be used is a survey with a quantitative approach. The selection of survey methods is because this study explains the causal relationship of hypothesis testing. While the quantitative approach is intended as an attempt to interpret and measure the data from research results in the form of numbers. The research data was collected through a survey that will be conducted on Seskoal soldiers in Jakarta. The data to be obtained will be analyzed using path analysis techniques to explain the influence between research variables, namely: (1) the influence of emotional intelligence (x1) on work motivation (X3). (2) the influence of discipline (X2) on work motivation (X3). (3) the effect of work motivation (X3) on decision making (X4). (4) the influence of emotional intelligence (X1) on decision making. (5) the influence of discipline (X2) on decision making (X4). (6) the influence of emotional intelligence (x1) on discipline (X2) of Seskoal soldiers.

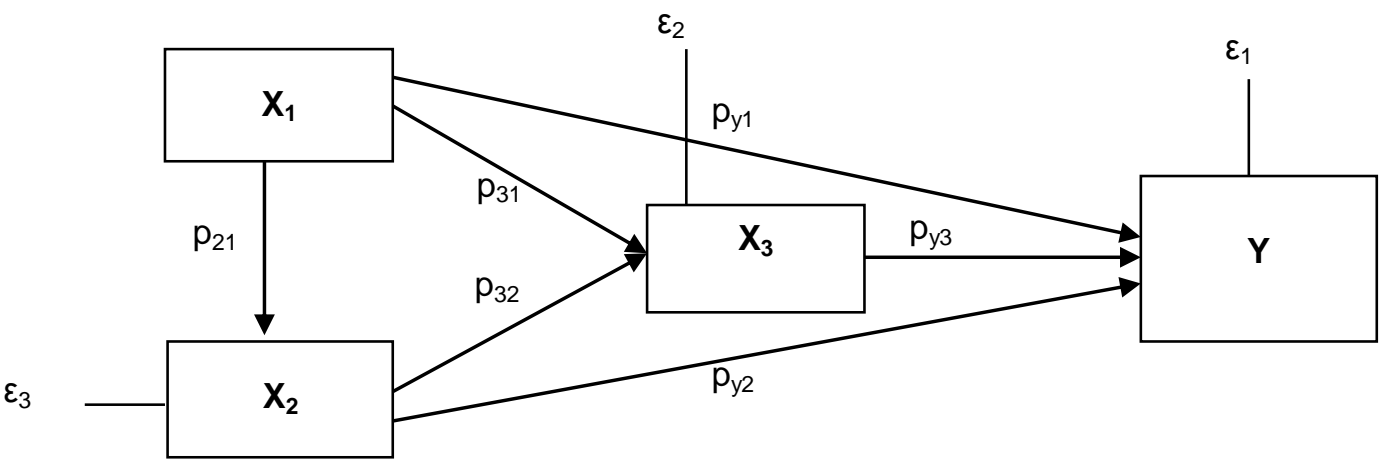

Based on quantitative research procedures, researchers conducted preparatory steps by explaining the background of the problem, formulating existing problems according to the results of the observations, and then the researcher making the research hypothesis. This is reinforced by the variable supporting theory according to the literature review and the results of previous studies in scientific journals, then the researcher creates a model of Path Analysis constellation which aims to test the influence between variables. The development of instruments for each variable is presented starting from conceptual definitions, operational definitions, instrument grids, instrument validity testing and reliability calculations. The results of the questionnaire were tabulated and tested with Path Analysis. The findings of this study will be discussed and interpreted according to the results of the analysis, which will then describe the conclusions and explain the logical implications that arise from the results of the research and follow up with proposed improvement efforts. The researcher will also provide suggestions based on the results of the research relating to the operational implications of the research to various parties related to the research problem. The data analysis used in this study is descriptive statistics and inferential statistics. Descriptive statistics were carried out in terms of descriptive data presentation, the size of the centralized tendency and the size of the crossing. Presentation of data in descriptive statistics using frequency distribution tables and then presented in the form of histograms. Central size is done by determining standard deviation and analysis of variance. The infertility statistics are used to test hypotheses using path analysis, which begins by using the normality test and linearity test. Data normality test 
will be carried out using the liliefors test and simple linearity test using simple linear regression. Then hypothesis testing uses path analysis by calculating path coefficients to find out how much direct influence between variables that influence the variables affected.

\section{Results and Discussion:-}

Data description includes decision-making variable data $(\mathrm{Y})$ called endegenous variable, emotional intelligence variable (X1) as exsogenous variable, and discipline variable (X2) and work motivation variable (X3) as intervening variables. Descriptions of each variable are explained in succession starting from variables $\mathrm{Y}, \mathrm{X} 1, \mathrm{X} 2$, and $\mathrm{X} 3$. Decision Making (Y), From the data obtained in the field which are then processed statistically into the frequency distribution list, the number of classes is calculated according to Sturges' rules, obtained by seven classes with a maximum score of 150 and a minimum score of 124, resulting in a score of 26. Results calculation of data obtained by an average of 134.99; standard deviation of 4.74; variance of 22.4285; median of 135.0; and mode equal to 133 . Grouping decision-making data can be seen in the frequency distribution table as follows

\begin{tabular}{|c|c|c|c|c|c|c|c|}
\hline \multirow{2}{*}{ No } & \multirow{2}{*}{ Kelas } & \multirow{2}{*}{ Interval } & \multicolumn{2}{|c|}{ Batas } & \multicolumn{3}{|c|}{ Frekuensi } \\
\hline & & & Bawah & Atas & Absolut & Relatif & Komulatif \\
\hline 1 & 124 & 127 & 123,5 & 127,5 & 5 & $5,43 \%$ & $5,43 \%$ \\
\hline 2 & 128 & 131 & 127,5 & 131,5 & 15 & $16,30 \%$ & $21,74 \%$ \\
\hline 3 & 132 & 135 & 131,5 & 135,5 & 35 & $38,04 \%$ & $59,78 \%$ \\
\hline 4 & 136 & 139 & 135,5 & 139,5 & 20 & $21,74 \%$ & $81,52 \%$ \\
\hline 5 & 140 & 143 & 139,5 & 143,5 & 14 & $15,22 \%$ & $96,74 \%$ \\
\hline 6 & 144 & 147 & 143,5 & 147,5 & 2 & $2,17 \%$ & $98,91 \%$ \\
\hline \multirow[t]{2}{*}{7} & 148 & 151 & 147,5 & 151,5 & 1 & $1,09 \%$ & $100 \%$ \\
\hline & & & & & 92 & $100 \%$ & \\
\hline
\end{tabular}

There are two axes needed in histogram making, namely the vertical axis as the absolute frequency axis, and the horizontal axis as the decision-making score axis. In this case, on the horizontal axis, the boundaries of the interval class are written, starting from 123.5 to 151.5 . These prices are obtained by subtracting 0.5 from the smallest data and adding a number 0.5 for each class limit at the highest limit. The histogram graph of the distribution of decisionmaking data is shown in the following figure.

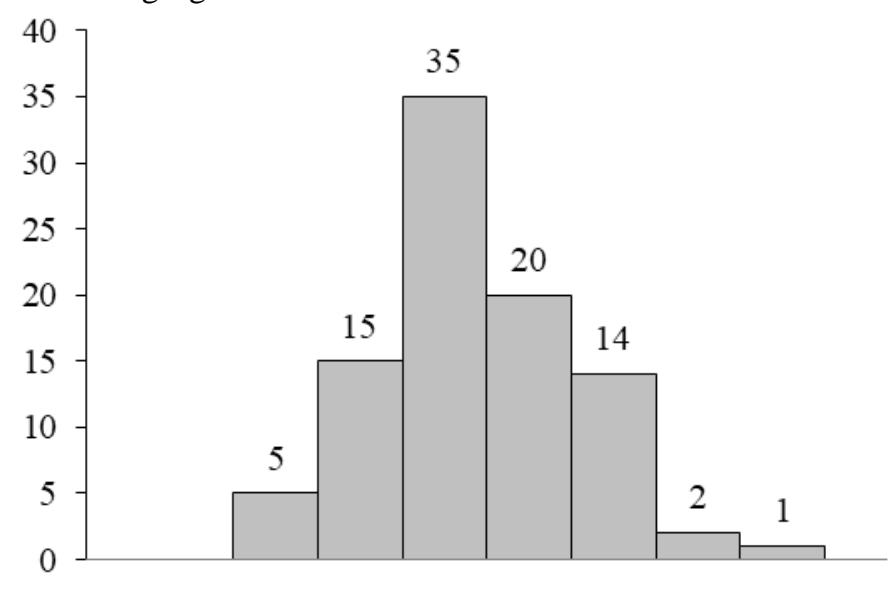

Emotional intelligence data has a range of empirical scores between 121 and 153 , so the range of scores is 32 . The results of the calculation of the data obtained an average of 136.73; standard deviation of 7.54; variance of 56.8594; median of 136.5; and mode equal to 136. Grouping emotional intelligence data can be seen in the frequency distribution table as follows. 


\begin{tabular}{|c|c|c|c|c|c|c|c|}
\hline \multirow{2}{*}{ No } & \multirow{2}{*}{ Kelas } & \multirow{2}{*}{ Interval } & \multicolumn{2}{|c|}{ Batas } & \multicolumn{3}{|c|}{ Frekuensi } \\
\hline & & & Bawah & Atas & Absolut & Relatif & Komulatif \\
\hline 1 & 121 & 125 & 120,5 & 125,5 & 6 & $6,52 \%$ & $6,52 \%$ \\
\hline 2 & 126 & 130 & 125,5 & 130,5 & 14 & $15,22 \%$ & $21,74 \%$ \\
\hline 3 & 131 & 135 & 130,5 & 135,5 & 18 & $19,57 \%$ & $41,30 \%$ \\
\hline 4 & 136 & 140 & 135,5 & 140,5 & 27 & $29,35 \%$ & $70,65 \%$ \\
\hline 5 & 141 & 145 & 140,5 & 145,5 & 15 & $16,30 \%$ & $86,96 \%$ \\
\hline 6 & 146 & 150 & 145,5 & 150,5 & 9 & $9,78 \%$ & $96,74 \%$ \\
\hline \multirow[t]{2}{*}{7} & 151 & 155 & 150,5 & 155,5 & 3 & $3,26 \%$ & $100 \%$ \\
\hline & & & & & 92 & $100 \%$ & \\
\hline
\end{tabular}

the histogram will then be made. There are two axes needed in making histograms, the vertical axis as the absolute frequency axis, and the horizontal axis as the axis of the emotional intelligence score. In this case the horizontal axis is written at the interval of the class interval, starting from 120.5 to 155.5 . These prices are obtained by subtracting 0.5 from the smallest data and adding a number 0.5 for each class limit at the highest limit. The histogram graph of the distribution of emotional intelligence data is shown in the following figure.

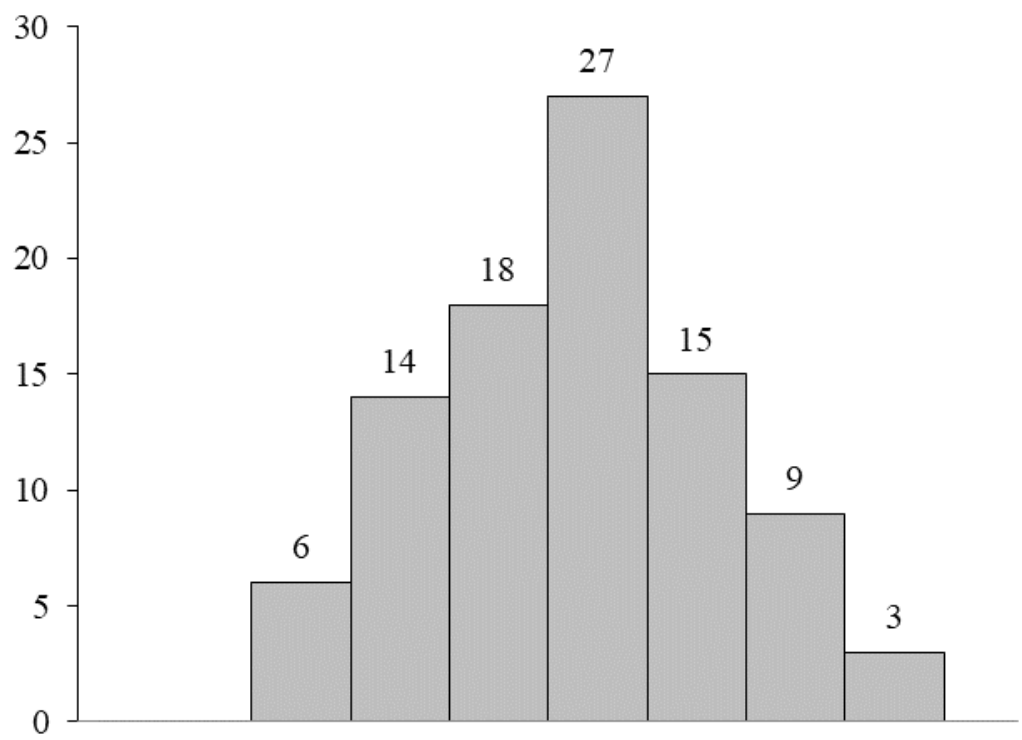

Discipline data has an empirical score range of 136 to 169 , so the range of scores is 33 . The results of the calculation of data obtained an average of 151.01; standard deviation of 6.29; variance of 39,5054; median of 151.5; and mode equal to 15 . The grouping of disciplinary data can be seen in the frequency distribution table as follows.

\begin{tabular}{|c|c|c|c|c|c|c|c|}
\hline \multirow{2}{*}{ No } & \multirow{2}{*}{ Kelas } & \multirow{2}{*}{ Interval } & \multicolumn{2}{|c|}{ Batas } & \multicolumn{3}{|c|}{ Frekuensi } \\
\hline & & & Bawah & Atas & Absolut & Relatif & Komulatif \\
\hline 1 & 136 & 140 & 135,5 & 140,5 & 5 & $5,43 \%$ & $5,43 \%$ \\
\hline 2 & 141 & 145 & 140,5 & 145,5 & 13 & $14,13 \%$ & $19,57 \%$ \\
\hline 3 & 146 & 150 & 145,5 & 150,5 & 23 & $25,00 \%$ & $44,57 \%$ \\
\hline 4 & 151 & 155 & 150,5 & 155,5 & 27 & $29,35 \%$ & $73,91 \%$ \\
\hline 5 & 156 & 160 & 155,5 & 160,5 & 19 & $20,65 \%$ & $94,57 \%$ \\
\hline 6 & 161 & 165 & 160,5 & 165,5 & 4 & $4,35 \%$ & $98,91 \%$ \\
\hline \multirow[t]{2}{*}{7} & 166 & 170 & 165,5 & 170,5 & 1 & $1,09 \%$ & $100 \%$ \\
\hline & & & & & 92 & $100 \%$ & \\
\hline
\end{tabular}

the histogram will then be made. There are two axes needed in histogram making, namely the vertical axis as the absolute frequency axis, and the horizontal axis as the axis of the discipline score. In this case, the horizontal axis is 
written at the interval of the class, starting from 135.5 to 170.5 . These prices are obtained by subtracting 0.5 from the smallest data and adding a number 0.5 for each class limit at the highest limit. The histogram graph of the discipline data distribution is shown in the following figure.

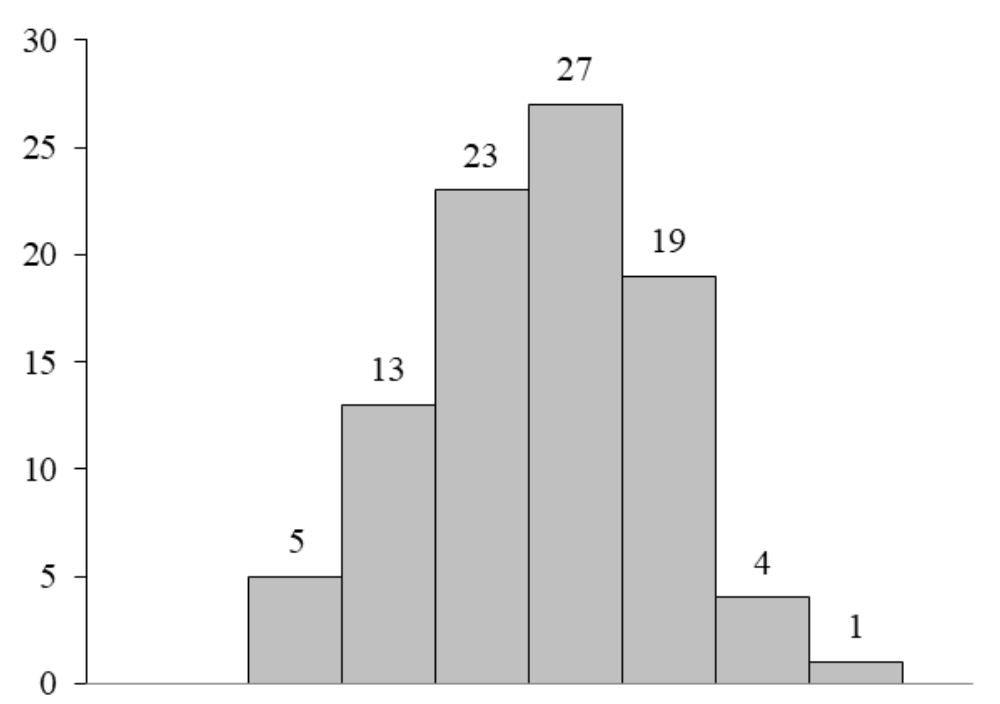

Work motivation data has a range of empirical scores between 134 and 168, so the range of scores is 34 . The results of the calculation of data obtained an average of 149.70; standard deviation of 6.77; variance of 45.7745; median of 150.5; and mode equal to 151 . Grouping work motivation data can be seen in the frequency distribution table as follows.

\begin{tabular}{|c|c|c|c|c|c|c|c|}
\hline \multirow{2}{*}{ No } & \multirow{2}{*}{ Kelas } & \multirow{2}{*}{ Interval } & \multicolumn{2}{|c|}{ Batas } & \multicolumn{3}{|c|}{ Frekuensi } \\
\hline & & & Bawah & Atas & Absolut & Relatif & Komulatif \\
\hline 1 & 134 & 138 & 133,5 & 138,5 & 4 & $4,35 \%$ & $4,35 \%$ \\
\hline 2 & 139 & 143 & 138,5 & 143,5 & 15 & $16,30 \%$ & $20,65 \%$ \\
\hline 3 & 144 & 148 & 143,5 & 148,5 & 16 & $17,39 \%$ & $38,04 \%$ \\
\hline 4 & 149 & 153 & 148,5 & 153,5 & 31 & $33,70 \%$ & $71,74 \%$ \\
\hline 5 & 154 & 158 & 153,5 & 158,5 & 19 & $20,65 \%$ & $92,39 \%$ \\
\hline 6 & 159 & 163 & 158,5 & 163,5 & 6 & $6,52 \%$ & $98,91 \%$ \\
\hline \multirow[t]{2}{*}{7} & 164 & 168 & 163,5 & 168,5 & 1 & $1,09 \%$ & $100 \%$ \\
\hline & & & & & 92 & $100 \%$ & \\
\hline
\end{tabular}

the histogram will then be made. There are two axes needed in making histograms, the vertical axis as the absolute frequency axis, and the horizontal axis as the axis of the work motivation score. In this case, the horizontal axis is written in the interval of the class, starting from 133.5 to 168.5 . These prices are obtained by subtracting 0.5 from the smallest data and adding a number 0.5 for each class limit at the highest limit. Histogram graph of the distribution of work motivation data as shown in the following figure. 


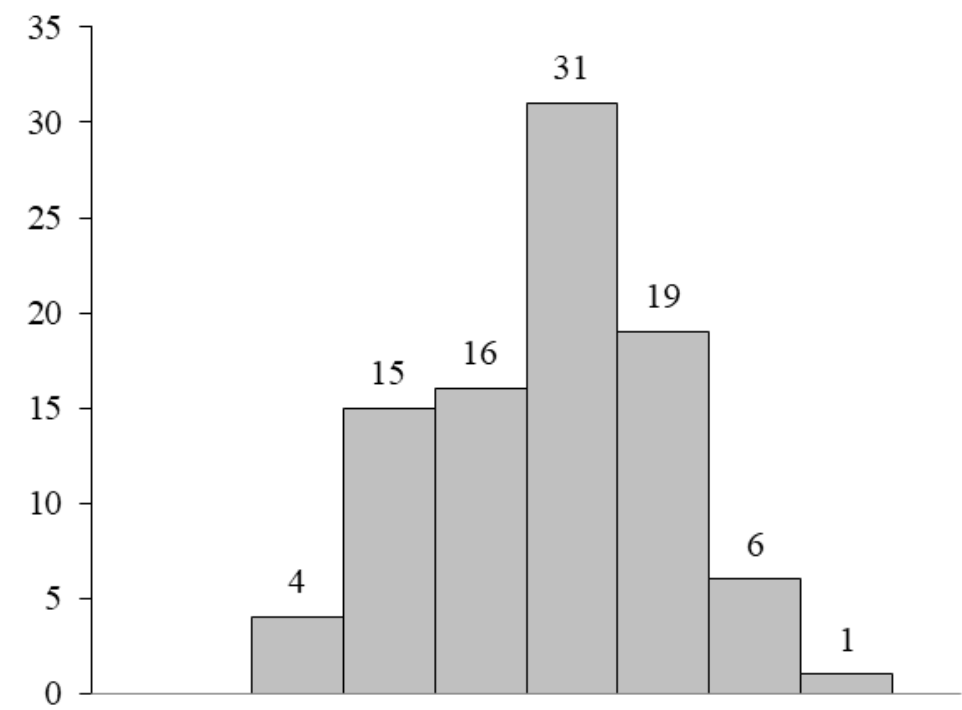

The recapitulation of the results of the calculation of descriptive statistics is shown in the following table.

\section{Rangkuman Statistik Deskriptif}

\begin{tabular}{lcccc}
\hline Keterangan & $\begin{array}{c}\text { Pengambilan } \\
\text { Keputusan }\end{array}$ & $\begin{array}{c}\text { Kecerdasan } \\
\text { Emosional }\end{array}$ & Disiplin & $\begin{array}{c}\text { Motivasi } \\
\text { Kerja }\end{array}$ \\
\hline Rata-rata & 134,99 & 136,73 & 151,01 & 149,70 \\
\hline Standard Error & 0,49 & 0,79 & 0,66 & 0,71 \\
\hline Median & 135,0 & 136,5 & 151,5 & 150,5 \\
\hline Modus & 133 & 136 & 152 & 151 \\
\hline Standar Deviasi & 4,74 & 7,54 & 6,29 & 6,77 \\
\hline Varians & 22,4285 & 56,8594 & 39,5054 & 45,7745 \\
\hline Rentang & 26 & 32 & 33 & 34 \\
\hline Terendah & 124 & 121 & 136 & 134 \\
\hline Tertinggi & 150 & 153 & 169 & 168 \\
\hline Jumlah Skor & 12419 & 12579 & 13893 & 13772 \\
\hline Ukuran Sampel & 92 & 92 & 92 & 92 \\
\hline
\end{tabular}

Terms of path analysis (path analysis) are estimates of exogenous variables on endogenous variables that are linear, thus the requirements that apply to regression analysis automatically apply to the path analysis requirements. The requirements that must be met in path analysis are that the study sample comes from a population that is normally distributed, the regression equation must be meaningful and linear, and the relationship between the variables in the model must be significant. In this regard, prior to testing the model, testing must first be carried out on the applicable requirements in the analysis of the line.

\section{Normality Test}

The data used in compiling a regression model must fulfill the assumption that the data comes from populations that are normally distributed. The assumption of normality basically states that in a regression model it must be normally distributed. The assumption test in this study was carried out by testing the normality of the data from the six research regression estimation errors to be analyzed. The normality test uses the SPSS program to find out whether the Y Top X regression is normally distributed or not whose results can be seen in the Kolmogorov Smirnov column (Sig.). 
Hasil Uji Normalitas Galat Taksiran Regresi

\begin{tabular}{lcccccc}
\hline & \multicolumn{2}{c}{ Kolmogorov-Smirnov(a) } & \multicolumn{3}{c}{ Shapiro-Wilk } \\
\cline { 2 - 7 } & Statistic & df & Sig. & Statistic & df & \multicolumn{2}{c}{ Sig. } \\
\hline Y Atas X1 &, 062 & 92 &, $200\left(^{*}\right)$ &, 986 & 92 &, 433 \\
\hline Y Atas X2 &, 074 & 92 &, $200\left(^{*}\right)$ &, 991 & 92 &, 802 \\
\hline Y Atas X3 &, 068 & 92 &, $200\left(^{*}\right)$ &, 969 & 92 &, 028 \\
\hline X3 Atas X1 &, 075 & 92 &, $200\left(^{*}\right)$ &, 973 & 92 &, 054 \\
\hline X3 Atas X2 &, 076 & 92 &, $200\left(^{*}\right)$ &, 982 & 92 &, 224 \\
\hline X2 Atas X1 &, 066 & 92 &, $200\left(^{*}\right)$ &, 988 & 92 &, 589 \\
\hline
\end{tabular}

The table above shows that the probability value (Sig.) Of all regression estimation errors is 0.200 . The probability value is greater than the significant level $(\alpha)$ of 0.05 , so all error data regression estimates are normally distributed. The overall results of the significance test and regression linearity are summarized in the following table.

Hasil Uji Signifikansi dan Uji Linearitas Regresi

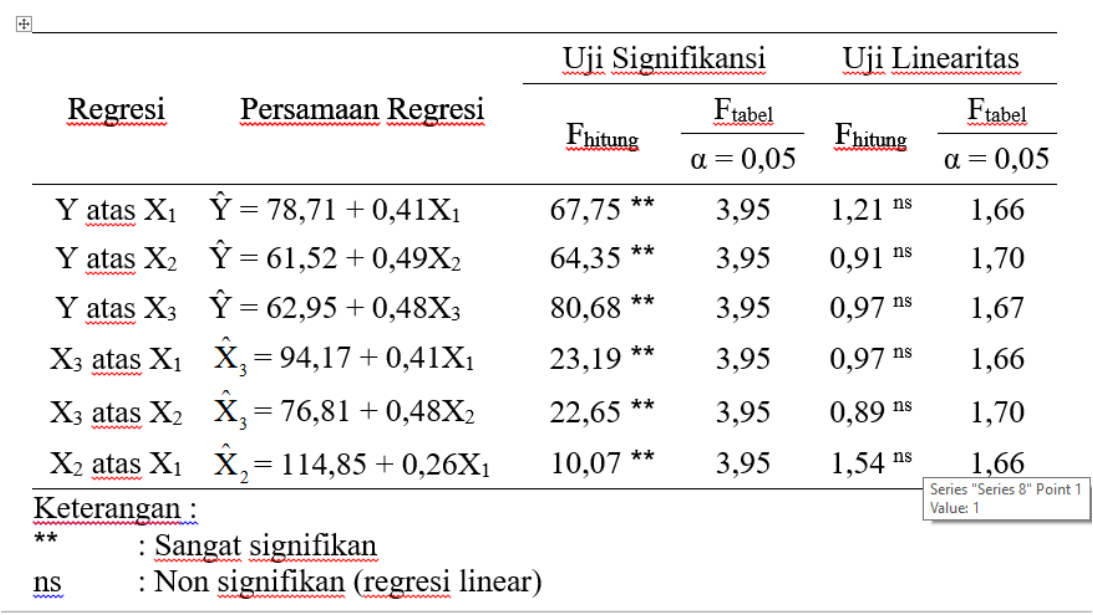

Based on the causally formed model theoretically a path analysis diagram will be obtained and then the coefficient values are calculated for each path. Before the calculation is done to test the causality model by using the path analyst method, the research data is tested first and has fulfilled all the necessary requirements. One very important requirement that must be fulfilled is the existence of a significant correlation between related variables and relating to one another. The relationship that has been proven above has not concluded the occurrence of a causal relationship between these variables. From the field data that has been processed and through the various tests required, the next step in testing the causality model is to conduct path analysis. From the results of the analysis in the previous section and the calculation process carried out in appendix 6 , it can be summarized as follows.

Rangkuman Hasil Pengujian Koefisien Korelasi

\begin{tabular}{|c|c|c|c|}
\hline \multirow{2}{*}{ Matrik } & \multicolumn{3}{|c|}{ Koefisien Korelasi } \\
\hline & $\mathbf{X}_{2}$ & $\mathbf{X}_{3}$ & $\mathbf{Y}$ \\
\hline $\mathbf{X}_{1}$ & $\mathrm{r}_{12}=0,317$ & $\mathrm{r}_{13}=0,453$ & $\mathrm{r}_{1 \mathrm{y}}=0,655$ \\
\hline $\mathbf{X}_{2}$ & & $r_{23}=0,448$ & $r_{2 y}=0,646$ \\
\hline $\mathbf{X}_{3}$ & & & $r_{3 y}=0, \frac{688}{\text { Series" }}$ \\
\hline
\end{tabular}

In connection with the division of the three models, namely the sub-structure of the first model, the sub-structure of the second model, and the sub-structure of the third model, it can be explained that the path coefficient in the substructure of the first model is the path that connects the emotional intelligence variable to the decision-making variable discipline towards decision-making variables, and pathways that connect work motivation variables to decision-making variables. The path coefficient value in the sub structure of the second model is the pathway that connects the variables of emotional intelligence to work motivation variables, and pathways that connect the disciplinary variables to work motivation variables. The path coefficient value in the sub structure of the third model 
is the pathway that connects the variables of emotional intelligence to disciplinary variables. A summary of the model can be seen in the picture as follows.

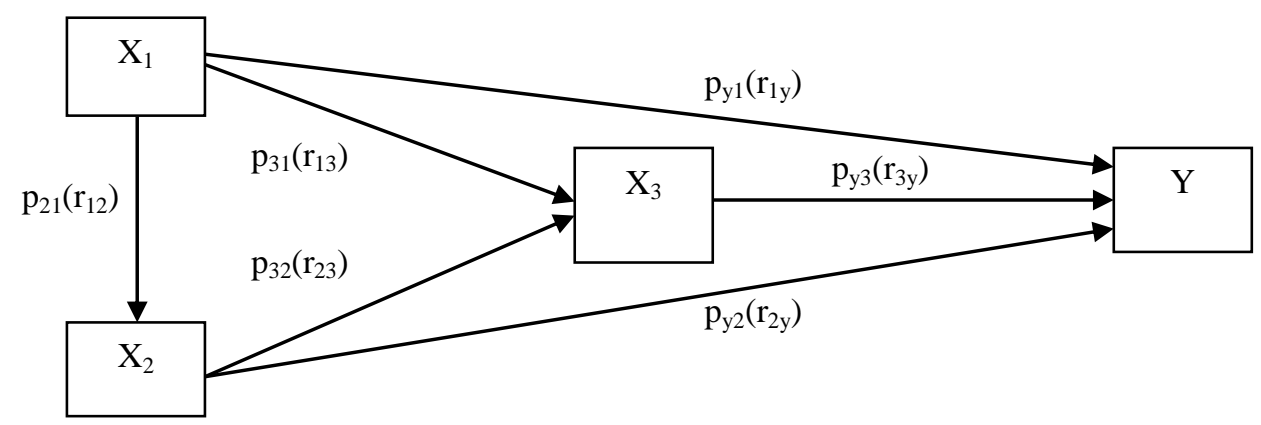

The results obtained after conducting a model analysis are used as a basis in answering hypotheses and drawing conclusions in this study. Explanation of the answers to these hypotheses can be described as follows:

1. The Positive Direct Effect of Emotional Intelligence (X1) on Decision Making (Y). The results of the analysis of the first hypothesis yield findings that emotional intelligence has a positive direct effect on decision making. Based on these findings it can be concluded that decision making is directly influenced positively by emotional intelligence. Increasing emotional intelligence will lead to increased decision making. Affecting soldiers or work partners is a process of interaction between soldiers and other soldiers that does not only occur in one-way communication processes, but in which various elements cannot be separated from one another. For example, the communication process that takes place between the leader and subordinates involves emotions, behavior, manners and others, all of which are closely related to the effectiveness of communication that is carried out and of course this will determine the high and low commitment of someone to keep doing things and work constantly an institution. At the same time it will also affect the results of work. In his research James D. Hess (2013) stated "Applying the skills of emotional intelligence to non-profit leadership and decision-making situations can improve the quality of decisions". Applying emotional skills will improve the quality of decisions. According to Jennifer S. Lerner (2014) states that "Emotional Intelligence constitutes a powerful and predictable sof driver decision". Therefore, it is assumed that emational intelligence has a direct effect on individual decision making by Seskoal soldiers.

2. Positive Direct Effect of Discipline (X2) on Decision Making (Y). The results of the second hypothesis analysis yield findings that the discipline directly influences the decision making. Based on these findings it can be concluded that decision making is directly influenced positively by discipline. Increasing discipline will lead to increased decision making. The results of this study are in line with the opinions of some experts, among them, according to Prijodarminto (in Tu'u, 2004) through a person's mental and moral temptation will be tested, through mental forging someone can overcome the problem with full fortitude and perseverance. Discipline will be realized through fostering from an early age, from a young age, starting from the family environment through education that is embedded from a young age which is increasingly fused in itself with increasing age. Discipline that is cultivated and fostered through training, education or planting habits that began early taught by parents in the family environment, began in childhood and continues to grow so that it becomes a very strong discipline. Discipline taught by parents from an early age will make it easier for students to deal with demand situations with a higher level of discipline, someone with discipline education will not show an easy attitude of anxiety. Discipline becomes the catalyst for someone to achieve success in learning because students have an awareness of the importance of norms, rules of obedience, and obedience that have been taught early in their families. Emotional intelligence in this study has a negative relationship with anxiety, so that the higher the emotional intelligence possessed by Seskoal soldiers, the lower the anxiety in undergoing basic military education and vice versa. Thus the second hypothesis in this study is proven. This means that the results of this study are supported by the opinion of Goleman (2000) which states that emotional intelligence is the ability to control emotional impulses, the ability to read other people's feelings, and the ability to build good relationships with others, more abilities a person has in motivating themselves, and endurance in the face of failure, controlling emotions and delaying satisfaction, and regulating the state of the soul.

3. Positive Direct Effect of Work Motivation (X3) on Decision Making (Y). The results of the analysis of the third hypothesis produce findings that work motivation has a direct positive effect on decision making. Based on these findings it can be concluded that decision making is directly influenced positively by work motivation. 
Increasing work motivation will result in increased decision making. When a leader is able to carry out activities and see the results of hard work in accordance with the expectations or goals of the organization, it also shows that someone will consistently do something. This consistency is caused by various motivating factors to carry out an organizational task, especially specific tasks in the organization led. As research conducted by Dr. Olaronke O. Fagbola (2015) states that "The study was established that the combination of locus of control, work motivation, and information use would improve decision-making". So it is assumed that work motivation has a direct effect on the decision making of individual Seskoal soldiers.

4. Positive Direct Effect of Emotional Intelligence (X1) on Work Motivation (X3). The results of the fourth hypothesis analysis provide findings that emotional intelligence has a positive direct effect on work motivation. Based on these findings it can be concluded that work motivation is directly influenced positively by emotional intelligence. Increasing emotional intelligence will result in increased work motivation. Goleman (1998), which includes aspects of self-motivating abilities, overcoming frustration, controlling heart pressure, managing moods, empathy, and the ability to work together. Furthermore, Goleman stated that intellectual intelligence factors (IQ) only accounted for $20 \%$ for successful careers, while $80 \%$ were contributed by other factors, including emotional intelligence. In addition, Segal (2000) states the importance of emotional intelligence, especially in terms of work. According to him emotional intelligence has an important role in the workplace; in addition it also plays a role in the family environment, society, romantic experiences and spiritual life. Even emotional awareness makes the mental state more attention so that it is possible to determine better choices about what will be done, how to maintain a balance between the personal needs and needs of others, and in choosing a spouse. Influencing work partners or subordinates is a way, technique and tips that can affect work in carrying out a task that must be carried out in accordance with the main tasks and functions of each, so that organizational goals are achieved. When work partners or subordinates can carry out their main tasks and functions continuously as they should, it can be assumed that the process of carrying out these basic tasks and work results in accordance with the objectives is an indication of high work motivation. Or in other sentences it is estimated / suspected that there is a direct influence of emational intelligence that a person has on work motivation. Someone who has high emotional intelligence will be able to control his emotions so that it can produce optimization on his work motivation. Starting from that, the idea of empowering emotional intelligence needs to be given more attention, so that they will be more able to motivate themselves to work well so that performance will increase. Although intellectual abilities and skills are very necessary to handle various operational tasks, emotional intelligence encourages them to be able to work together, have a moral sense, and have high social sensitivity. Human intelligence will make people more creative. Humans use spiritual intelligence to distinguish between good and bad, and to imagine possibilities that have not yet been realized, to dream, to aspire, to lift themselves up from humility. According to Muhammad Mohsin Atiq (2015) in his research, he stated that "Our study contributes to the field of motivation due to emotional intelligence. When the emotions of the employees are hijacked, they are not motivated towards their job ". Therefore it is estimated / suspected that there is a direct influence of emational intelligence that a person has on work motivation.

5. The Positive Direct Effect of Discipline (X2) on Work Motivation (X3). The results of the fifth hypothesis analysis yield findings that the discipline directly influences positively on work motivation. Based on these findings it can be concluded that work motivation is directly influenced positively by discipline. Increasing discipline will result in increased work motivation. All programs planned and carried out by Seskoal are closely related to the level of needs of the target group whose needs of the target group are almost the same. Unlike the case with non-formal education target groups, where the material and curriculum must be tailored to the needs of participants or who needs it. The success of all these programs is very much determined by the level of ability of Seskoal soldiers in understanding the characteristics they have. Therefore understanding and mastery of basic principles of discipline by Seskoal soldiers is a must. According to Rahmi Fentina Sari (2017) in her research stating that "a teacher has a high work" work discipline will get a high work motivation in doing the task. Because with the understanding and mastery of the principles of the discipline, it is assumed that the understanding and mastery of Seskoal soldiers on the basic principles of discipline will greatly influence the work motivation of Social Security itself directly.

6. Positive Direct Effect of Emotional Intelligence (X1) on Discipline (X2). The results of the sixth hypothesis analysis found that emotional intelligence has a positive direct effect on discipline. Based on these findings it can be concluded that discipline is directly influenced positively by emotional intelligence. Increasing emotional intelligence will lead to increased discipline. The results of this study are in line with the opinions of several experts including Tennyn Tjahjaningrum (2013) in her research explaining the effective contribution of emotional intelligence and discipline to the anxiety of Bintara Kowal students in undergoing military basic education of $52.60 \%$ so that there were $47.40 \%$ other variables that gave the influence of anxiety in addition to 
the two emotional intelligence and discipline variables studied included the process of adjusting to the new environment, self efficacy, independence and adversity quotient. According to Prijodarminto (in Tu'u, 2004) through a person's mental and moral forging will be tested, through mental forging someone can overcome the problem with full fortitude and perseverance. Discipline will be realized through fostering from an early age, from a young age, starting from the family environment through education that is embedded from a young age which is increasingly fused in itself with increasing age. Discipline that is cultivated and fostered through training, education or planting habits that began early taught by parents in the family environment, began in childhood and continues to grow so that it becomes a very strong discipline. Discipline taught by parents from an early age will make it easier for students to deal with demand situations with a higher level of discipline, someone with discipline education will not show an easy attitude of anxiety. Discipline becomes the catalyst for someone to achieve success in learning because students have an awareness of the importance of norms, rules of obedience, and obedience that have been taught early in their families. Emotional intelligence in this study has a negative relationship with anxiety, so that the higher the emotional intelligence possessed by Seskoal soldiers, the lower the anxiety in undergoing basic military education and vice versa. Thus the second hypothesis in this study is proven. This means that the results of this study are supported by the opinion of Goleman (2000) which states that emotional intelligence is the ability to control emotional impulses, the ability to read other people's feelings, and the ability to build good relationships with others, more abilities a person has in motivating themselves, and endurance in the face of failure, controlling emotions and delaying satisfaction, and regulating the state of the soul. Thus it is suggested that with emotional intelligence a person will not be trapped in anxiety, resignation, or depression in the face of difficult challenges or setbacks. People who have high hopes are not easily depressed compared to other people as they move through life in pursuit of goals, generally not so anxious, and emotional stress free. In influencing the warrior is a process of interaction between soldiers and other soldiers that not only happens in one-way communication process, but in which various elements are gathered which cannot be separated from one another. For example, the communication process that takes place between the leader and subordinates involves emotions, behavior, manners and others, all of which are closely related to the effectiveness of communication that is carried out and of course this will determine the high and low commitment of someone to keep doing things and work constantly an institution. At the same time it will also affect the results of work. Therefore it is assumed that emotional intelligence has a direct effect on the discipline of Seskoal soldiers.

\section{Conclusion:-}

Based on the results of the calculation of research data and the results of data analysis that has been described, some conclusions can be obtained as follows;

1. Emotional intelligence directly influences the decision making of individual Seskoal soldiers. This means that good emotional intelligence will improve the decision making of good Seskoal soldiers.

2. Discipline directly influences the decision making of Seskoal soldiers. This means that high discipline will improve the decision-making of high-ranking Seskoal soldiers.

3. Work motivation directly influences the decision making of individual Seskoal soldiers. This means that high motivation will improve the decision making of good Seskoal soldiers.

4. Emotional intelligence directly influences the motivation of working Seskoal soldiers. This means that good emotional intelligence will increase the motivation of working good Seskoal soldiers.

5. Discipline directly influences the motivation of working Seskoal soldiers. This means that high discipline will increase the work motivation of high-ranking Seskoal soldiers.

6. Emotional intelligence has a direct effect on the discipline of Seskoal soldiers. This means that good emotional intelligence will improve the discipline of good Seskoal soldiers 


\section{Refrences:-}

1. Adair, John., How To Grow Leaders, The Seven Key Principles of Effective Leadership Development, Great Britain: Kogan Page limited, 2005.

2. Amran. "The Influence of Work Discipline on the Performance of Employees of the Department of Social Affairs of Gorontalo Regency". In the Ichsan Gorontalo Journal, Volume 4 No. 2. Matters 2397-2413. Gorontalo: Ichsan Gorontalo University. 2009

3. Arikunto, Suharsimi. Research Procedure A Practical Approach. Jakarta: Rineka Cipta. 2006.

4. As’ad, Moh., Industrial Psychology Yogyakarta: Liberty, 1998.

5. Asnawi, Sahlan, Motivation Theory in Industrial and Organizational Psychology Approaches, Jakarta: Studia Press, 2002.

6. Bauck, Ross. Human Motivation and Emotion. Canada: John Wiley \& Sons, Inc., 1988

7. Bedeian, Arthur G. and Glueck, William F. Management New York: The Dryden Press, 1983.

8. Caerto, Samuel, Modern Management, New Jersey: Pracice-Hall, Inc., 1997.

9. Davila, Tony; Epstein, marc J; Shelton, Robert, Making Innovation Work, New Jersey: Peason Education Inc., 2006.

10. Davis, Keith \& John W. Newstrom, Human Behavior at Work, Singapure: McGraw Hill, 1998.

11. Donovan, JJ., Work Motivation. The Hanbook of Industrial, Work and Organizational Psychology, London: Sage Publication, 1990

12. Dubrin, Andrew, The Complete Ideal Guides Leadership, is translated by Tri Wibowo BS, Prenada, 2005.

13. Erez, Miriam and Henk Thierry, Work Motivation in the Context of a Globalizing Economy, New Jersey. 2010

14. Freedman, Mike and Benjamin B. Tregoe, Strategic Thought to Realize Organizational Vision, Jakarta: Pt. Gramedia Main Library, 2004

15. Goleman, D.2009. Emotional Intelligence to Reach the Peak of Achievement. Jakarta: PT. Gramedia Main Library.

16. Handoko. T. Hani. Personnel Management and Human Resources. Yogyakarta: BPFE. 2001.

17. Harrison, E. Frank. The Managerial Decision Making Process, Boston: 2012.

18. Hasibuan, Malayu. Human Resource Management. Jakarta: PT Bumi Aksara. 2007

19. I Wayan Siwantara, Effect of Professional Competence and Work Motivation and Organizational Climate on Work Discipline and Performance of Bali State Polytechnic Lecturers. 2009

20. Jason A, Colquitt, A. Lepine, Jeffery, J Wesson, Michael, Organizational Behavior Improving Performance and Commitment in The Workplace, New York: McGraw-Hill, 2009.

21. Luthans, Fred, Organizational Behavior (10th edition of Indonesian), Jogyakarta: Publisher ANDI, 2006.

22. Mangkunegara, Anwar Prabu. Bandung Human Resource Management: PT Remaja Rosdakarya. 2009

23. Marturano, Antonio and Jonathan Gosling., The Key Consept Leadership, London: Routledge, 2008.

24. Mathis, R. L., and J.H. Jackson. Human Resource Management, book1, Translation. Jakarta: Salemba Empat. 2006.

25. Mega Arum Yunanda, Effect of Work Environment on Job Satisfaction and Employee Performance. 2011

26. Nawawi, Hadari, Human Resource Management for Competitive Business, Jokyakarta: Gajah mada University Press, 1997.

27. Nursasongko, Ginanjar Sigit. "Analysis of the Effect of Leadership, Work Environment, and Compensation on Employee Performance (Study of the Regional Personnel Agency of Pemalang Regency)". Thesis Undergraduate Program, Faculty of Economics and Business, Diponegoro University. Semarang: Diponegoro University. 2012.

28. Riduwan and Engkos Achmad Koncoro, How to Use and Use Path Analysis, Bandung: Alfabeta, 2007.

29. Robin, Stephen, A Judge Timothy, Organizational Behavior, New Jersey: Person Education Inc, 2007

30. Robin, Stephen, Organizational Behavior: Concepts, Controversies, Applications, Hadyatna Pujaatmaka Translation, Jakarta: Prenhalindo, 1996.

31. Schuler, and Jackson. Human Resource Management: Facing the 21st Century. Jakarta: Erlangga. 1999

32. Septianto, Dwi. "The Effect of Work Environment and Job Stress on Teacher Performance (Study at PT Pataya Raya Semarang)". Thesis of the Bachelor Program in the Faculty of Economics, Diponegoro University. Semarang: Diponegoro University. 2010

33. Sugiyono. Statistics for Research. Bandung: CV Alfabeta. 2007

34. Tennyn Tjahjaningrum, Emotional Intelligence, Discipline and Anxiety in Bintara Kowal Students in Undergoing TNI-AL Military Basic Education, Persona, Indonesian Psychology Journal, May 2013, Vol. 2, No. 2, h. 122-130. 